Tourism 2020, 30/1

\author{
Jacek Kaczmarek \\ https://orcid.org/0000-0003-1750-1592 \\ University of Lodz \\ Institute of Urban Geography and Tourism Studies \\ Urban Geography Department \\ jacek.kaczmarek@geo.uni.lodz.pl
}

\title{
THE ALEATORIC ASPECT OF LITERARY TOURISM: AN EXAMPLE FROM HAVANA
}

\begin{abstract}
Abstrakt: The expression literary tourism is an established term which rarely raises controversies. It fits well into a positivist way of thinking about tourism reality. An analysis of Cuban literature, as well as field study conducted in Havana, however have pointed to the need to reconstruct the definitions of literary tourism that are currently in use as there are many contexts and current definitions are insufficient. The article presents an aleatoric approach based on the phenomenon of chance while exploring the literary space of Havana.
\end{abstract}

Keywords: literary tourism, chance, claves, Havana.

\section{INTRODUCTION}

A tourist's world is a set of events: events that have passed, are taking place, or will happen in the future. Each has meaning and is based on probability, therefore they do or do not exist. Events are divided into intended or accidental. Reality experienced during a journey becomes a tourist's reality and this can be expressed in words. Thus, literary tourism is sometimes identified with finding reality in an unhurried movement through a world of intended and accidental events happening in literary space during journeys stimulated by literary works (based on Arystoteles, 2003; Wittgenstein, 2012) The aim of this article is to define new horizons in the existing literature on the subject of literary tourism. Among the numerous academic papers where researchers define literary tourism and its empirical and analytical scope, there is a notable publication with a pronounced methodological theme (Roszak, Godlewski, 2013). Its authors propose an inspiring approach to the evaluation and presentation of tourism potential in places of literary travel. If, however, the path presently indicated is extended, we will obtain the following contexts for literary tourism:

- literary tourism research methodology,

- methods of organizing literary space,

- a classification of tourists' attitudes to a literary work within the space in which its author has set it.
The author focuses on the third aspect which is the experience of space in a specific literary and geographical context. It is assumed that an intriguing analytical motive would be to understand the attitudes of the reader/tourist who travels to the sources of literary works. The reader/tourist has already been placed at the centre of research in humanist works. This is because a reader is sometimes seen as the co-author of the interpretation of a book, which becomes 'alive' as a result of active reading. Adopting this convention of literary perception leads to the following conclusion: "The reader as an active factor of interpretation, is a part of the generative picture of the text itself" (Eco, 1994, p. 9). The writer often challenges readers and does not let them remain passive, summoning them to actively interpret the text. The reader should not be a spectator but a creative partner (Czermińska, 2000). The target of a literary journey is of great importance, but the destination does not have to be the essence of the trip. The wandering itself is crucial, searching for traces of narration in space, but this approach requires appropriate methodological perspectives (Zajas, 2008).

The main thread of thought in the proposed research procedure will be the inclusion of the category of chance into literary tourism. An aleatoric approach based on chance will be discussed using the example of literature 
whose main arena is Havana. This city is presented in two historical contexts, the first being the 1950s through works by G. Cabrera Infante: Delito Por Bailar el Chachacha and Tres Triste Tigres (Cabrera Infante, 2009, 2016). The second is the 1990s and the poignant picture of Havana presented by P.J. Gutiérrez in Trilogia sucia de la Habana (Dirty Havana Trilogy) (Gutiérrez, 2019). The field study was conducted in the 2010s and took advantage of the aleatoric approach to a reader/tourist experiencing literature space in Havana. The basic research method was the auto-ethnographic approach (Botterill, Platenkamp, 2012) where field research requires direct involvement on the part of the researcher in the interpretation of the literary work at the place of its 'action' (Photo 1).

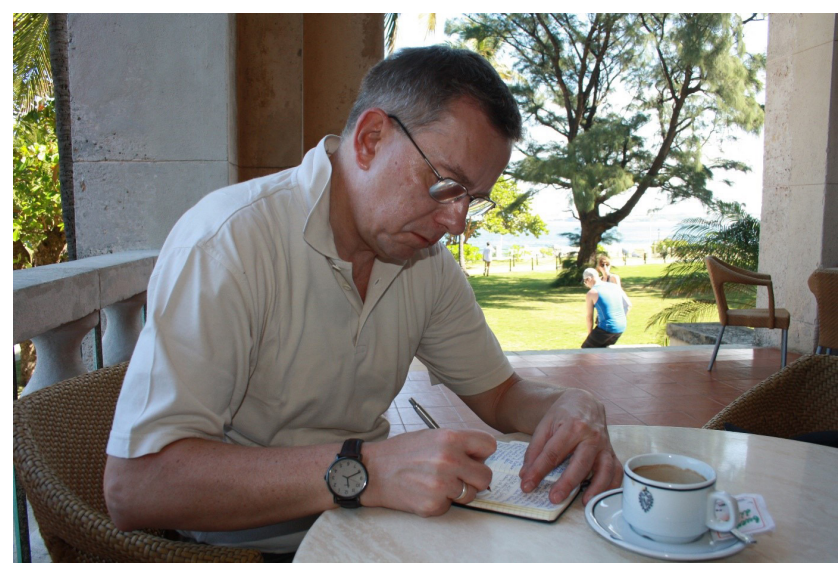

Photo 1. Hotel Nacional de Cuba - field study Source: S. Kaczmarek (February 2015)

Auto-ethnographic studies were supplemented with a 'phenomenological unveiling' which makes it possible to discern the place where space and time converge as one of the exact instant when something is happening (Heidegger, 1996). This moment sometimes comes when we are entering the world of a literary work while directly experiencing literary space. In another ontological approach, the 'phenomenological unveiling' is an a priori experience (Stein, 1995). The origins of the research, i.e. the choice of literature, the literary journey and the field study methods, can be summarized by the famous words of Winnie-thePooh: "[...] Poetry and Hums aren't things which you get, they're things which get you. And all you can do is to go where they can find you" (Milne, 1928, p. 125). Havana is, beyond a shadow of a doubt, a city which captures the reader/tourist researcher and leads him/ her along a path of aleatoric experience to an understanding of local lives through literary works. In this situation, there is nothing left but to "move forward and this reader, always standing aside the text or, rather, sitting on its shoulders or following closely behind, is placed in the text" (Eco, 1994, p. 15).

\section{EXPERIENCING CHANCE}

Chance defines unplanned events but is above all a statistical concept which, nevertheless, has considerable influence on every individual's life. Let us start our deliberations from some examples of chance affecting the contexts of events recorded on the pages of literary works. At the beginning, let us delve into the intriguing verses written by F. Pessoa as Álvaro de Campos (Pessoa, 2016, p. 189):

The bloom of an accidental meeting

Of those who are meant to remain strangers forever...

One uninterested glimpse thrown

By an anonymous woman...

A curious look of a child led by the hand

By an absentminded mother...

Accidental words exchanged

With an accidental traveller

During an accidental journey...

Great pain that all things are mere fragments An endless road...

A slightly different approach can be found in a literary puzzle of J. Cortazar, Rayuela (Hopscotch): “[...] a chance meeting is something least accidental in our lives and (that) only those set a date who write to each other on lined paper, and squeeze toothpaste out of the tube to the very end" (Cortázar, 2013, p. 8). Is chance really accidental? Or, as Wittgenstein (2012, p. 5-6) remarks, having already happened, did it have to be an inherent element of the essence of being:

2.012 In logic, nothing is accidental. If something occurs in the current state of affairs, this possibility must have been determined from the start.

$2.0121[\ldots]$ If things can happen in status quo, it must be inherent to them.

2.913 Each thing is, in a way, in the space of possible status quo.

Thus, we may assume that chance is inevitable, inherent in the scenario of the course of events. What is an event? It is a primary concept. It can be assumed, however, that events are real situations which have specific temporal and spatial parameters. Events are defined as 'temporal-real objects' which are experienced empirically and have their own 'history', i.e. a course and duration (Kaczmarek, 2005; Kobiela, 2011). Every event, as mentioned at the beginning of the article, has meaning and is based on probability. The literary examples presented here carry the idea of aleatoricism, i.e. the randomness of everything that happens every day, in art, thinking and human existence. Chance is the basis of probability and mathematics is a discipline where the 
aleatoric approach is unavoidable. Let us return, however, to art and its various forms. Wandering around an urban literary space may bring some surprises and may knock the wanderer from the traditional experience of space. A variety of chances appear everywhere:

What is Rome like? It is what it is. You leave home not knowing what you're going to see on your way. Today, I'm going to the same bar as usual and I'm discovering Chinese figures over the bar, looking just like the famous Chinese terracotta army statues. I'm coming into the office to find a piece of paper with written on it that the landlord is a cannibal (Mikołajewski, 2011, pp. 411-412).

Surprise or amazement makes the wanderer confused. Chance introduces confusion into spatial orientation which, in turn, creates subsequent chances. In this way, one can discover strange cities by leaving the banal, ordinary guidebook behind in the hotel room. In this situation, chance marks a route across the varying spaces of literature for the straying tourist:

Among the many ways of getting lost in Rome, there is also the ordinary type when you realize that you don't know where you are. Apart from an absolute lack of a sense of direction, its source for me is the Tiber, in its windings, which overturn awareness through its atypical bends (Mikołajewski, 2011, p. 17).

Chance leads not only to tourists getting lost, but also roaming within their own awareness. A literary tourist discovers the world which is rooted in a literary work, but what happens later is sometimes surprising and unpredictable. Thus, following in the footsteps of literature can be unanticipated, as well as dangerous because the changing state of tourist awareness may show them who they really are.

The influence of chance on human fate has also been analysed in film. Of course, chance may determine different paths of human wanderings in a hostile world. However, the stable, permanent value is our attitude to changing reality. Being human should be the basic value, regardless of who we are and in what circumstances we have found ourselves. K. Kieślowski presented this issue in Przypadek (Incident). No matter what path fate will indicate, the person we become still depends on our choices. People living in ancient times treated human life as a tragedy, and fate was the 'screenwriter' weaving the cloth of accidental life. However, in wearing this 'cloth', one could be either decent or a rogue. Sometimes, tossing a coin will determine our future and our further life will depend on chance:

The main character Lazare (from "The Cartographer" by Guillaume Jan), a young Parisian, walks around, carries a city plan found in the street, and is unfamiliar with the reality of Central-Eastern Europe. With no money and unable to speak the language, he travels as a hitch-hiker or on foot acrossk Bosnia, Albania, Romania, Moldavia,
Ukraine and Czechia. His way back from Sarajevo to Paris is complicated, as it depends on chance and on the people he meets en route. His guides are usually emigrants returning home for holidays from Belgium, Italy or France, but also music makers playing at weddings, circus artists, an American missionary and a farmer looking for seasonal workers to pick tomatoes (Konończuk, 2014, pp. 183-184).

The hero of The Cartographer draws a map of his journey on the back of the map he has found. In this way, a new map is created whose key consists of accidental meetings and the subsequent choices of roads eventually leading to Paris. Lazare does not use tourist guidebooks; he writes a new guide himself. Life, literature and tourism are determined by chance. Mathematically calculated hope does not fit into our lives and the journeys we experience. From an aleatoric perspective, cognitive priority is given to unlikely events. Can something unlikely happen during a journey? The answer is affirmative because the occurrence of an event even if of low statistical significance is not impossible. Let us ask another question: do unlikely events have little impact on explaining reality? In the opinion of statisticians, such events should be rejected in terms of low probability. It turns out, however, that we cannot reject phenomena which remain outside the limits of statistical significance, i.e. fall within the range where $p=0.05$. Such statistical significance is very important in literary tourism, especially when it exposes the role of chance. That is why, in literary tourism, we must allow epistemological truth for phenomena having low statistical significance. This is not a particularly insightful or revolutionary statement. Professional statisticians suggest that the limits of low statistical significance (i.e. where $\mathrm{p}=0$ ) should be crossed boldly. Conclusions from research should not be based only on the level of statistical significance (Wasserstein, Schirm, Lazar, 2019). The key parameters of literary tourism include surprise and imagination, which help to surpass the schema contained within the limits of statistical significance. After all, "in the universe, no dream, no matter how absurd and illogical, is wasted. A dream contains a hunger for reality, a pretence that obliges reality, invisibly turning into a debt, and a claim, and a debt security which demands to be covered" (Schulz, n.d., p. 5). Dreams cannot be contained in conventional representation. The aleatoric approach has been best defined and used in music but aleatoricism is not an artistic trend which is popular or well understood. First of all, we should explain the meaning of the aleatoric approach whose meaning echoes in a string quartet composed by W. Lutosławski, in 1964.

In this piece of music, Lutosławski uses the technique of, so-called, restricted aleatoricism, which allows chance to an extent that serves the purpose of the rhythmical and expressive enrichment of music, and at the same time does not limit the composer's full power over the 
final shape of the piece of music. The quartet consists of small sections (which the author calls "mobiles"), performed in a certain sequence. With the exception of synchronic places marked in the notation, each of the musicians plays their part completely independently of other musicians. The independence of the part is so advanced that individual performers do not always have to know what the others are playing at that moment. With this type of structure, a traditional music score is not possible (there is only the 'special book of voices'), because setting the vertical precisely would make it impossible for the musicians to follow their own cadence, individual rubatos, accelerations, slowings down and lengths of fermata. Nevertheless, the musical notation provides necessary information about the music itself and the necessary agreement between the performers. Thus, the quartet is an attempt to perform a completely new kind of chamber music. (Gwizdalanka, 1998, p. 368)

Thus, literary tourism, played on an aleatoric note, must give tourists an opportunity to choose their own way, take their own decisions. A literary trail or a tourist guidebook should be dismantled and its deconstruction should result in experiencing the place visited individually. The writers of the books referred to here also suggest aleatoric thinking at a time when the work is being created and interpreted, as well as while searching for traces of literature in specific tourist realities (Kaczmarek, Kaczmarek, 2015). Cabrera Infante (2016, p. 373) suggests the following creative solution:

\begin{abstract}
Along with the book, the reader would receive a set of letters for the title and some dice. Using these three elements, everybody could create their own book. It would be enough to toss the dice. If they threw a 1 and a 3, the player would choose the first and third words or word number four, [...]. The order of words on the list, also arbitrary, as well as their distribution by the reader would depend on the throw of the dice. Perhaps in this way, true poems would be created, and the poet would be the creator or a troubadour again. Aleatoricism would be an approximation or metaphor.
\end{abstract}

The creative procedure described above takes place to the rhythm of bachata, i.e. a dance from the Dominican Republic, going back to the musical traditions of Dominican peasants and referring also to the Cuban bolero. It is a sensual dance, sometimes obscene, which expresses sensitivity, betrayal, alienation, despair and hopelessness. There is, however, another understanding of bachata as a noisy party, playful conversation or witty retorts. This other face perfectly expresses the spirit of aleatoricism. Chance is a necessity in our life. It is sometimes a joke, an irony, a retort or reaction to all kinds of sarcastic remarks and taunts. To wander the streets of Havana, looking for literary spaces, is to dance bachata. It is this particular dance that expresses the spirit of aleatoric Havana better than the salsa which is heard all around. Musical rhythms must be these 'mobiles' from Lutoslawski's music which create an opportunity to choose tourist paths through literary Havana. The sounds of claves let the tourist construct their own interpretation in literary tourism among the amazing architecture of astonishing Havana:

It's true that Cuban music is primitive, but it has a joyful charm; it surprises with a strong beat and something hard to define, poetic, which flies up high together with the maracas and guitar, while the drums keep them tied to the ground and the claves - two sticks which make music - are like a stable horizon (Cabrera Infante, 2016, p. 199).

These rhythms are what creates a 'stable' horizon for visiting Havana where a great number of performances (literary experiences) appear in the space of the Cuban capital. These examples from under a Caribbean sky clearly indicate that literary tourism has many undertones and cannot be specified through a single definition. Thus, the concept of literary tourism needs to be reconstructed.

\section{THE SCOPE OF LITERARY TOURISM}

The academic and conceptual dimension of literary tourism has established cognitive boundaries. Popular definitions of cultural tourism are not controversial and fall into a fixed range. They fit well into the positivist approach to tourist reality. In Polish academic literature, the basic definition of literary tourism as a product was proposed by Zmyślony (2001, pp. 22-23):

[...] literary tourism comprises all activities which accom-
pany readers' short journeys to and stays at destinations
related to literary works and their authors, outside of
permanent places of residence and work. The main
potential functions of tourist activity originating from
a fascination with literature include cognitive and learn-
ing functions, the cultural education function and the
ethnic function.

The next attempt to specify the conceptual scope of literary tourism was made by Buczkowska (2008, p. 58): "Literary cultural tourism is a form of cultural tourism, where the main motivation is to reach specific destinations related in various ways to literature (fiction and non-fiction), which allows extensive contact with culture".

Still other aspects in the definition of cultural tourism were stressed by Mikos von Rohrscheidt (2008, p. 68), who stressed the importance of subjective contexts as well as personal reflections during a journey: 
"[...] a cultural literary journey in the tourist sense where the leading theme is the author (or authors) and their works, while the visited destinations are an occasion to reflect on this creation". These attitudes were collected by Stasiak (2009, p. 224) who suggested the following solution with regard to the definition of literary tourism:

Literary tourism is an important part of cultural tourism, comprising all tourist journeys which follow in the footsteps of great writers and their works, and which create an opportunity for deeper reflection on and personal experience of literary works. Literary tourism understood in this way consists of two basic forms of travel: biographical tourism and literary fiction tourism.

Tourism researchers have introduced the theme of literary tourism into studies of sustainable tourism. Small changes have been proposed which do not significantly affect the concepts established: "[...] literary tourism is understood as a form of cultural tourism comprising all journeys which are inspired by literary works and their film adaptations, as well as the lives of their authors" (Kowalczyk, Kulczyk, 2010, p. 232).

It should be added that the arena of literary tourism may be composed of various spaces. Traces of literary fiction and authors' biographies are followed in both literature and literary space (Wawrzyniak, 2010). Recent studies on literary tourism have not brought any new concepts and current publications have little usefulness. An aspect often analysed is the literary potential for specific areas (Roszak, 2016). The development of the subjective trend looks promising; it involves observing and analysing the behaviours and experiences of a travelling reader/tourist (Korpysz, 2019). We must, above all, see the reader in the authentic literature space which was entered as a tourist. Then, the reader/tourist, traversing tourism space, moves from point $X$ to point $Y$ which are tourist attractions or other sightseeing destination points. As a result, we will obtain three logical categories of tourist behaviour:

- planned behaviour - the tourist travels across the space following a pre-set route between points $X$ and $Y$. The points on the way have been set and everything has been carefully planned, e.g. the individual stages of a tour.

- targeted behaviour - tourists know the location of the places which they would like to see. However, the route between them may change, depending on the circumstances, interests or predispositions of the visitor.

- accidental behaviour - the tourist knows only the starting point of the journey and the route chosen is determined by chance. The direction sometimes depends on an unexpected impulse as he/she has no specific destination in mind. The starting point is known, but the route and destination are a question of chance events (Kaczmarek, Kaczmarek, 2015; Płocka, 2013).

Literary tourism requires diversity in constructing a tourist product because the place and the type of literature are the basis of the tourist experience. We cannot, then, describe a single literary tourism, there is no universal definition of this kind of travelling. There are many types of literary tourism and they cannot be encapsulated in a single formula. Hence the aleatoric approach proposed for Havana because the place and literature enforce such an approach on the reader/tourist. It was chance that was responsible for the inspirations of the Cuban literary works mentioned in the Introduction, as well as for the organization of contemporary literary space in Havana.

Literature, space and tourism are studied in many academic disciplines and it is worth looking around and noticing that there is other academic work. An interesting view of the spatial links between literature, space and tourism is presented by literary scholars who have developed the domain of geopoetics. According to White, one of its pioneers, it is a poetic opening to the world and to the links between humans and the Earth (White, 2011). In the traditional understanding of literary tourism, the idea of geopoetics is usually disregarded, which is regrettable as it enriches a geographical approach to research concerning literary journeys as well. Geopoetics sensitizes the reader/tourist, and introduces a poetic point of view into the world inhabited and discovered. Literary tourism and the poetics of space often walk hand in hand along city streets. The paths leading through an area and the sites visited by tourists, can be classified according to the categories of the poetics of space. We deal here with the agency of literature in relation to specific places in geographical space. This agency is revealed in a practice referred to as literary tourism, i.e. journeys motivated and organized based on the places where a book's plot is set and the writer's biography (Konończuk, 2014). The poetics of space has an influence on the course of literary journeys. Here are the geopoetic categories that can be distinguished:

- indirect places - areas/sites experienced according to a model proposed by a writer (e.g. literature-based guides).

- spaces without traces - areas/sites from which the characters have been removed. They have been erased from memory and do not appear in literary records. The reader looks for their traces.

- unclosed territories - areas/sites presented in the form of a text of culture (literary text) which are an invitation presented to the reader, encouraging him/her to set out on a journey (a meeting, experiencing reality as geography, understanding the visited spaces) (Kaczmarek, 2016). 
This discussion leads to questions about the essence of literary tourism and the force which pushes tourists out of their homes to travel to exotic (or not so exotic) literary spaces. The causative factors of reader/tourist behaviour will be identified. The stimulators of such activity are the character of the literary work, as well as the atmosphere and mysteriousness of the visited areas, and the attitude of the tourist. The course of a literary journey also depends on the relationship between the author and the reader/tourist. The latter does not remain passive when reading the text but creates his/ her own places in the spaces of the literature visited. This creativity depends on the reader's intuition, imagination and sensitivity, while the factor intensifying the experience of a literary work at the place where it is set, is often chance.

\section{LITERARY SPACE IN HAVANA}

The aleatoric contexts of literary tourism in Havana are not accidental. Havana is a city whose complicated wholeness consists of diverse fragments, unyielding to morphological and social classifications which stem from its intricate historical, geographical, cultural and social contexts. Literature cannot be different from those; it has been created in Havana and tells about this wounded city:

It's hot all the time. Perhaps in the early morning the heat will subside. I left only one small window open overlooking the south. You can see the whole city from there, which - dark and quiet - suffocates below in the silver light of the moon. It looks as if it has been bombarded and abandoned. It's falling apart, but it's beautiful - this damned city where I have loved and have hated so much (Gutiérrez, 2019, p. 287).

Arriving at night, the tourist is informed that they are about to land at José Marti airport in Havana. It is dark all around and only individual lights can be seen. In contrast, the arrivals hall is crowded and full of ideological vigilance. Arriving tourists are checked carefully. Passport and luggage controls are excessively celebrated so that dissolute enemies of the system cannot enter. In the night, you will not see a joyful, dancing city. If the traveller sets foot on Havana in winter, they will still feel extreme heat. But the night will conceal the ruins of the huge, 'damned' city:

Berta is seventy-six years old. She lives alone on the eighth floor, the last but one in a tall building in San Lázaro in Havana Centrum. She goes to the balcony and suddenly feels depressed. Everything around looks as if it's been bombed. Just ruins. The only sound coming from below is the muffled murmur of a devastated city.
It's been a while since Berta decided not to even open the balcony door (Gutiérrez, 2019, p. 287).

The central part of the city looks depressing (Photo 2).

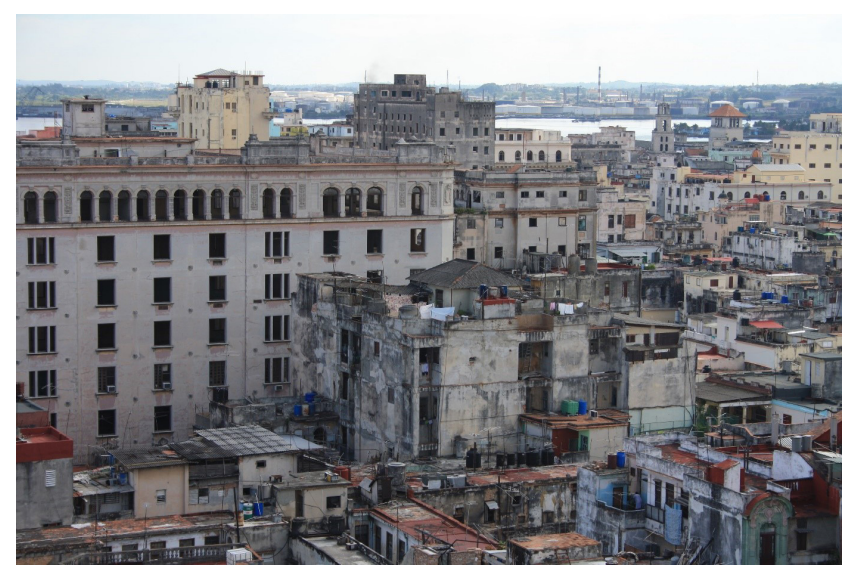

Photo 2. The panorama of the city from Edificio Bacardi Source S. Kaczmarek (February 2015)

Tourists delight in the former grandeur of Centro Habana and they are surrounded with a glamorous past. A stroll along San Lázaro is a journey between two worlds: the former and the one that exists today. You can clearly see the great past and the gloomy present. People are sitting on the thresholds of dilapidated houses; they live in shared flats, supervised by local revolutionary committees. Cubans are smiling and greeting visitors, very noticeable in San Lázaro which is a beautiful, charming, wasted world. Centro Habana is alsoa good place to observe the visited unknown world:

In the late afternoon, I got myself a glass of strong rum on ice [...]. At this time of day, everything becomes golden, so that was when I watched the world. In the north - a light-blue and unpredictable sea, made of gold and the skies. In the south and east - an old city, damaged and withered by time, salt, wind and human negligence. In the west - modern districts with high-rise buildings. Everywhere, the people are different, just as the hum of their voices and music (Gutiérrez, 2019, p. 287).

A different look at Havana after a glass of rum does not change the facts. The ruined city has destroyed the minds and souls of its inhabitants. The Portuguese have sad eyes, but Cubans have sad souls. Their spontaneous joyfulness is often a mirage, a façade built to defend them from the visitors: "[...] I am always happy when I meet intelligent and self-confident Negroes, not just people who never look you in the eye and have this damn, shrunken mentality of slaves" (Gutiérrez, 2019, p. 287).

The damage in the hearts and souls of Havana dwellers is terrifying; the climate and communism will wreck 
everything and everybody. Even hope is buried under the ruins of houses standing along Malecón Boulevard. Life goes from day to day and it is easier to catch a glimpse of Florida than to find the lost faith in life:

What was I waiting for? For nothing. I was just waiting. Here, everybody is waiting. Day after day. Nobody knows what they are waiting for. The days pass by. And the brain is slowly going numb. It's ok. It's good to have a numb brain because you don't think then (Gutiérrez, 2019, p. 287).

Havana is sometimes an illusion. On the surface, $\mathrm{Ha}$ bana Vieja is colourful, covered in icing sugar, and polite (Photo 3). But on the inside it is empty, falling apart. A powdered face does not have a soul.

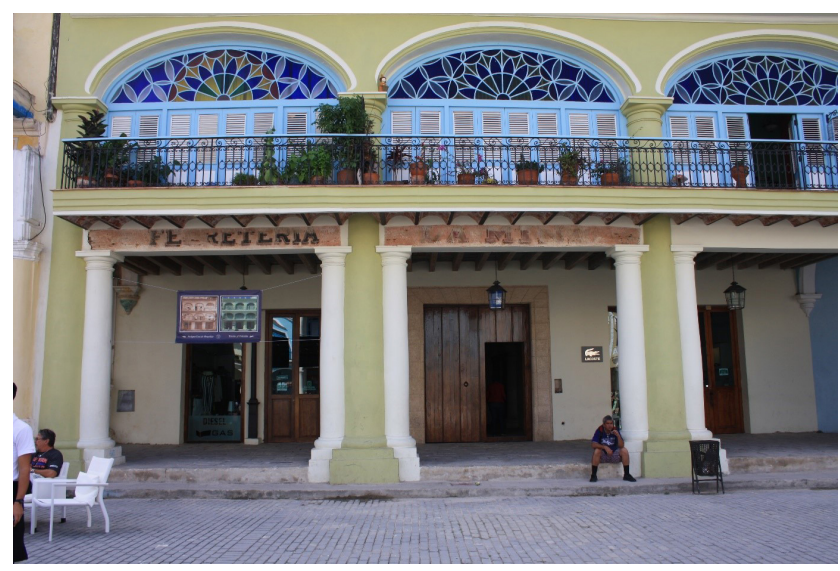

Photo 3. Habana Vieja

Source: S. Kaczmarek (February 2015)

Music, which in the Caribbean comes straight from the heart, is a well-prepared commercial product. Everything is for sale. Even the nobility of attitudes and behaviours has become cheap.

But poverty also has different faces. Perhaps the easiest to notice is the meanness or, rather, the narrowing of the spirit. You become a pathetic, greedy and calculating type. Your only concern is how to survive. The hell with nobleness, solidarity, politeness, pacifism (Gutiérrez, 2019, p. 210).

The street festival of cadging money from dopey tourists goes on incessantly. It seems to them that they have reached the Cuban paradise, it is only that Havana dwellers are somewhat sad. It is hard to believe in the authenticity of the omnipresent salsa. Even rum and cigars are mere commodities and their legend has vanished unnoticed. The inhabitants have assumed this attitude for a reason. It is not the Cubans' character that prompts the behaviours described in the "Dirty Havana" trilogy. The Cubans simply had no alternative; they had become victims of communism. It is difficult to be a noble person when hunger kills all feelings:
It was when the worst hunger ever had begun in Cuba. It was in 1991.[...] It was in July or August 1994. For four years, the whole country had been starving in complete chaos, but Havana was most heavily affected. [...] The crisis was really deep and affected us all, filtering through our minds and souls (Gutiérrez, 2019, p. 41, $45,162)$.

In such conditions, it was hard to keep a serene and fun attitude when each day was a fight for survival. The present situation is different that at the end of the $20^{\text {th }}$ century, but painful wounds have not healed. Wandering along the streets of Havana sometimes resembles dark tourism, pushing reflexive, academic literary tourism to the side.

An observant wanderer will notice a significant diversity in the egalitarian socialist society on the streets of Havana. It is a fact that white Cubans walk with their heads up. Their skin colour is surely a pass to a career. You can see many uniformed police officers who also feel confident in these ruined yet charming parts of Centro Habana. After all, someone has to keep an eye on socialist order. The tourists will soon leave this beautiful, wasted world behind.

The excerpts from the "Dirty Havana" trilogy leave no illusion - a literary journey across Havana cannot be elegant, composed, sensible tourism. It should be an aleatoric, passionate and filthy experience of the city, like fast, panting sex in the ruins of once grand houses: "Sex is an exchange of fluids; sex is saliva, panting breath, sharp smells, urine, sperm, shit, microbes and bacteria. Or there's no sex. If sex is limited to tenderness, ethereal moods and spirituality, it's simply nothing" (Gutiérrez, 2019, p. 10).

In Havana, literary tourism for sensitive, delicate tourists is a misunderstanding. Life in this loved and hated city is subject to chance. Havana is not a mawkish attraction for tourists walking along literary trails with multi-lingual guidebooks in hand. A spirited tourist would march toward the revitalized older part of the city - this postcard-like imagination of the Cuban paradise (Photo 4 ).

Havana must be touched from off the beaten track. A walk along the neglected yet exciting Avenida de Belgica will lead a leisurely traveller to the Central Railway Station, a place rarely visited by foreigners. A chance tourist may, undisturbed, look at the impressive art deco building, from the early $20^{\text {th }}$ century. Over the platforms, there are remarkable riveted steel structures. The former life of this place has disappeared somewhere; there are not many passenger trains left. Next to the station, there is a square where you can rest. If an accidental tourist sits down on a bench, they will become a part of ordinary, everyday Havana for a while. A place frequented by local people who chat to strangers who have stopped there. Some drink vodka, 


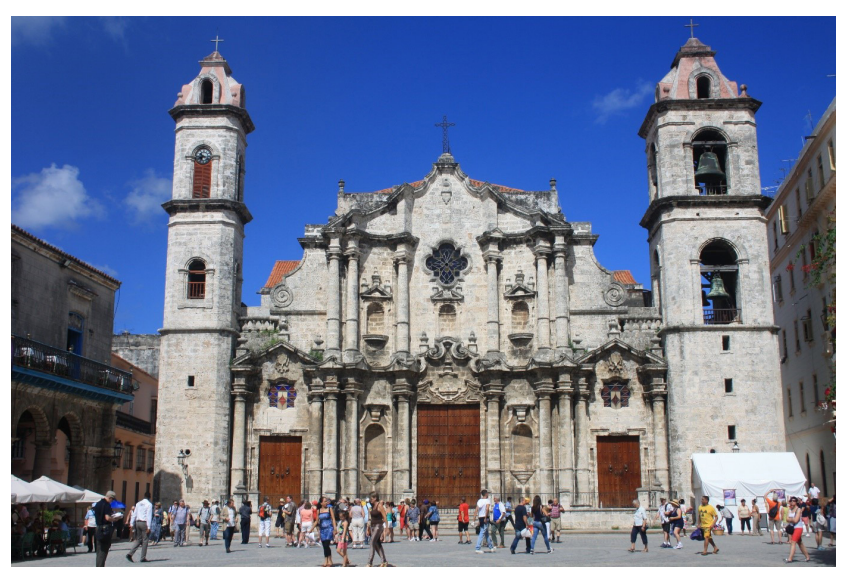

Photo 4. Cathedral Square

Source: S. Kaczmarek (February 2014)

others stroll with families. The stranger tries to talk in Spanish, shyly and, at least for a moment, the tourist becomes a part of the less recognized city. For a moment, he or she is an acquaintance, no matter how much money they have in their wallet. There is a need for authenticity, even when the tourist enters dangerous areas. Otherwise, the genuine experience of literary space in Havana will be replaced with 'hygienic' visits to popular tourist sites.

Some parts of Havana have always been evaluated in the same way through the years. San Lázaro Avenue was not a delight to the eye in the 1950s, either. However, it was not a ruin, or a terrifying area, it was the life stage for those who had arrived in the capital of Cuba:

We returned to see something different. San Lázaro. I don't like this street. That is, I want to say that at the first glimpse, in the beginning, it looks metropolitan, like a street in Paris, Madrid or Barcelona, but the very next minute, it turns out to be average, profoundly provincial, and next to Maceo Park, it changes into one of the most depressing and ugliest avenues in Havana. Merciless in the sun, dark and unfriendly in the night, it has only a few pleasant places - Prado, Beneficiencia and the University steps (Cabrera Infante, 2016, p. 346).

When the tourist is striding along San Lázaro towards the Vedado district, then into Neptuno Street, on a small hill they will see the monumental edifice of Havana University. There is the eye-catching statue of Alma Mater and the breath-taking, majestic steps. Tourist guidebooks say that it is a popular meeting place (Photo 5).

Personal experience may be surprising. On days free of work, the steps are guarded by a uniformed policeman who stops people from entering the university premises. But the steps are delightful.

The functional areas are changing their position in space. The contemporary reader/tourist may not find the places described in books because they have moved somewhere else:

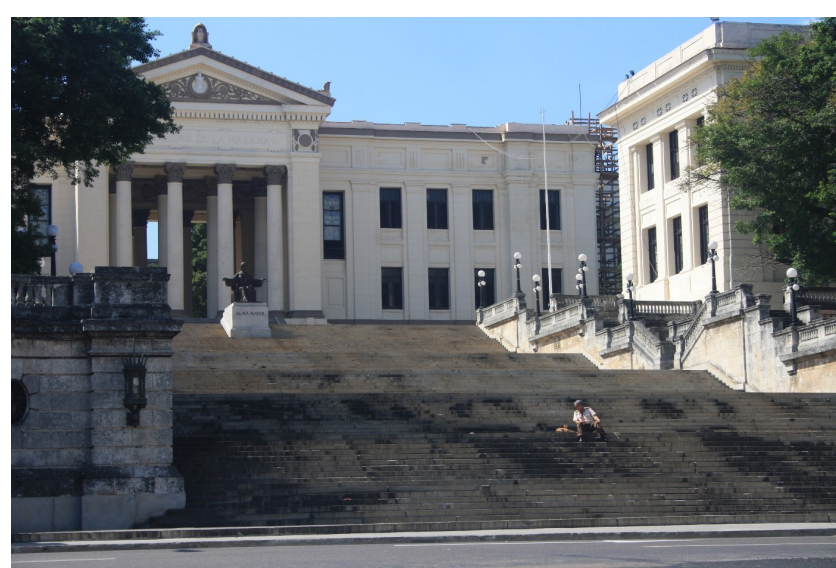

Photo 5. The University in Havana Source: S. Kaczmarek (February 2014)

It was simply the centre, that's it. Later, this centre moved to Prado, just as before, it had to be in Cathedral Square or in Plaza Vieja, or by the City Hall. As the years went by, it was moving up, as far as Galiano and San Rafael and Neptuno, and now it is in La Rampa. I wonder where it will finally end up - this moving centre, which, interestingly, is moving just like the city and the sun, from the east to the west (Cabrera Infante, 2016, p. 338).

The new functional sectors are better maintained and they attract more interesting people. They also offer a range of services and this is how the district is gaining a metropolitan character. La Rampa is extremely busy. It does not matter that most of the cars are old American road cruisers or Soviet vehicles. Sometimes you can see new cars of famous marques, too. The street looks brighter then, you can feel a lighter and more joyful atmosphere. Cuba is beginning to change, which can be seen in the space of the city: "Later, he led us down the section of the street which the Cubans call La Rampa, full of shops, lights and people walking up and down. It's quite all right" (Cabrera Infante, 2016, p. 192).

Regrettably, other areas were not so lucky. This is often the fate of places losing their important functions: "Finally, everything started to close to an end. Slowly, the district [Centro Habana - author's note] stopped being what it had been before. It was inhabited by different people: primitive Negroes and all sorts of boors arriving from the back country" (Gutiérrez, 2019, p. 10).

The discovering of literary space in Havana must include an emblematic place: the Malecón Boulevard. A stroll along the shore, from the harbour to de Velado should be aleatoric. Chance should rule the collection of tourist experiences in Malecón:

The most wonderful thing in the world is to walk ahead along Malecón, while a cyclone is wreaking havoc all around. You walk and sometimes you think. Sometimes you don't think. It's better not to think, but it is very difficult to achieve, nearly impossible. You must be used to that. [...] Now, the rain has turned into a real downpour. There isn't a single living soul in the whole of Malecón. 
It's only five o' clock, but the overcast skies have already turned the day into an evening. Grey, cold and damp light, unusual on this island, always full of fluorescent, blinding light. The pale afterglow slipping through the curtain of rain, salt and iodine. I'm hiding behind a pillar and waiting for the downpour to subside (Gutiérrez, 2019, p. 138).

Malecón is, above all, a meeting place. You can see all sorts of people there, it does not matter who they are and where they come from. They may be representatives of high society or suspicious individuals from the Cuban underworld. To get to know Havana, you must spend quite a long time sitting on the wall at Malecón. It is where questionable and short-lasting relationships are made. This boulevard embodies social Havana (Photo 6).

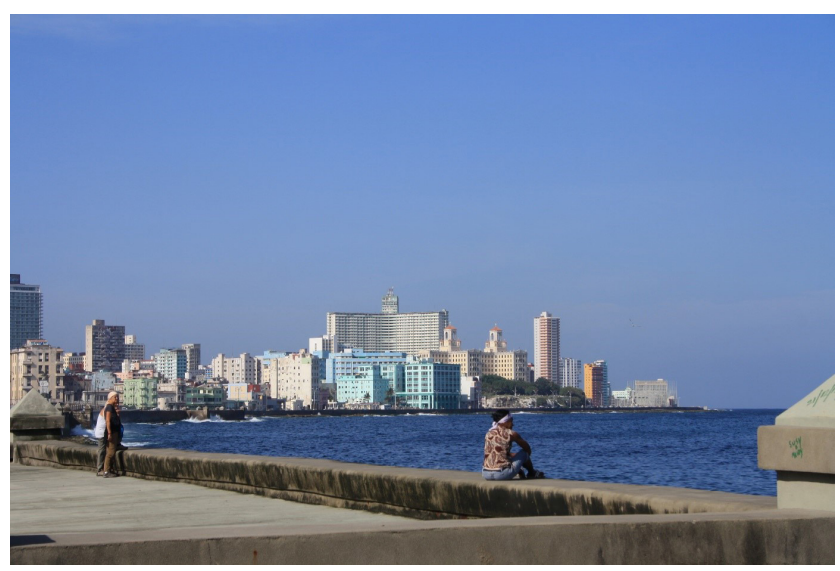

Photo 6. Malecón

Source: S. Kaczmarek (February 2015)

When you decide to go to Malecón, you absolutely must surrender to fate:

We talked for quite a few hours at Malecón and we were getting to like each other more and more. We were joking, laughing, teasing each other a little. At 1 a.m. we could swear we had always been friends. We stopped talking for a moment (Gutiérrez, 2019, p. 59).

The Malecón Boulevard can be admired or despised... (Photo 7).

... but nobody can stay indifferent to it; neither the inhabitants nor the tourists. However, you should not plan your stay there. A tourist walking westwards along the Malecón Boulevard is unavoidably heading towards the majestic towers of the Nacional de Cuba Hotel:

The hotel was exquisite. It cost a lot but it was worth the price. If the Cubans have learnt something from us, it is the sense of comfort, and the Nacional is a luxury hotel. What's more, their service is irreproachable. We woke up after dark and went for a walk nearby (Cabrera Infante, 2016, p. 191).

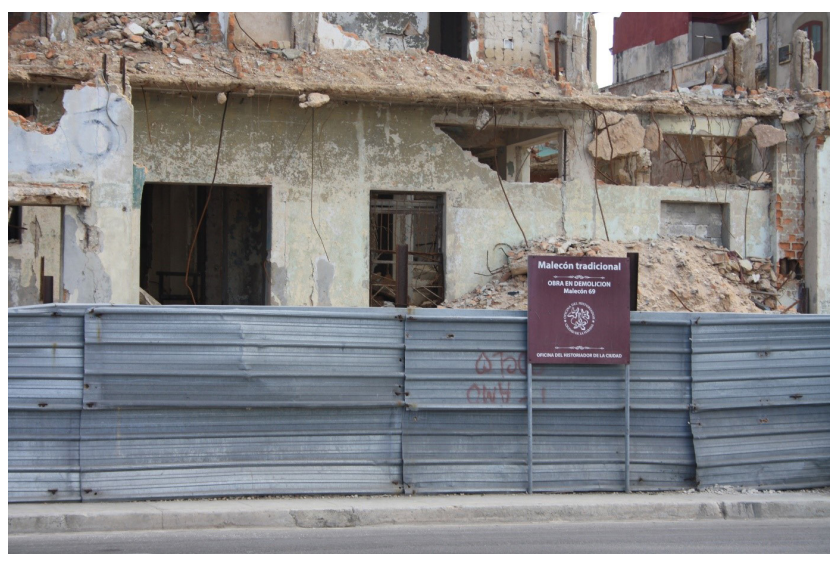

Photo 7. Malecón - the ruins of the boulevard Source: S. Kaczmarek (February 2015)

The Nacional de Cuba has become a legend and a place in which people dream of staying. The building is really magnificent and attracts tourists with its promised luxury. Despite renovation and restoration of its former grandeur, the Hotel Nacional still carries the stigmata of communist ideology. The staff have many features typical of socialist 'entrepreneurship'. They work more slowly than in other hotel chains and are more focused on their own business than on the guests' needs. The legend is crumbling but visitors who arrive for a short time will not notice that it is a facade of the Cuban legend. A longer stay would let them see the many cracks. What is left is sentiment and distance from the irritating and beautiful building. Well, legends are whimsical sometimes.

Cabrero Infante and Gutiérrez enjoy the same entertainment places. Both authors refer to the same sites and events which take place there:

We wanted to see Tropicana - a nightclub which advertises itself as "the most fantastic cabaret of the world". To Mrs Campbell, it was the sole reason for that trip (Cabrera Infante, 2016, p. 207).

I paid a short visit to Las Vegas. Las Vegas is eternal. It has always been there and will remain. It was in Las Vegas where she sang boleros. The same piano is standing in the corner, bottles are still kept under the bar counter, rum is still served on ice (Gutiérrez, 2019, p. 59)

Entertainment places in Havana do not change and the Nacional Hotel offers a variety of exciting performances. An interesting concert is given by Grupo Company Segundo an ensemble who stress their connections with the Buena Vista Social Club. The performance was organized most skilfully and salsa ruled the stage. The price was not too high - just 25 CUC. In other circumstances, it is worth watching the Cabaret Parisien in a show about the history of Cuba. After a concert, the group invites the audience to a common dance evening in the rhythm of salsa and samba. It is worth trying such 
opportunities. The entertainment continues regardless of time, so the tourist will find it not only in Las Vegas but in many other places as well.

Cuban literature has its own rhythm set by the authors. Careful reading, feeling the sound of the words, lets the reader discover the musical rhythm in the literature. In Cabrera Infante's short stories, we can hear cha-cha as the rhythm of literature should stimulate the rhythm of visiting the city. One must read and listen carefully to follow the rhythm of cha-cha:

She looked at me. She looked at me with her opal olive urine eyes. She looked at me eating and smiling. She was eating in an almost perfect manner, if we ignore the slight Americanism, which made her move the fork from her left hand to the right one [...] (Cabrera Infante, 2009, p. 47).

Music resonates in Havana at every step you take. Even if it is played for commercial reasons, its roots let us reveal the meaning of Cuban nature. Let us not be misled by the facade of Cuba and Havana; the city can be discovered, but it has to be understood. Literature is a good way to achieve this goal.

Literary tourism in Havana must be spontaneous and practiced during the reader/tourist's intuitive wandering. The shabby door to the city, the dingy Havana which the writers had experienced, has been left half-open:

Naked reality is always the best. Severe and brutal. A reality which you see all around you in the street. You grasp it in your hands, carry - if you're strong enough - and transfer onto paper. And that's it. Just that. No retouching (Gutiérrez, 2019, p. 59).

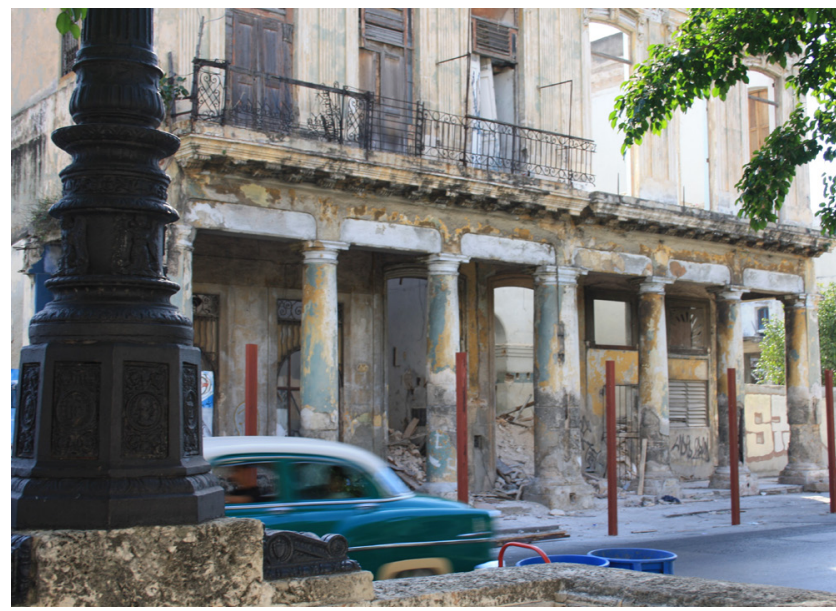

Photo 8. Dilapidated Old Havana

Source: S. Kaczmarek (February 2014)

Readers are invited by these authors to find adventure. Academic, 'hygienic', groomed literary tourism simply does not pass the test.

\section{CONCLUSIONS}

In literary tourism, time is a key category of cognition and experience. Without the temporal aspect, explaining the phenomenon of travelling in the footsteps of literature is sometimes seriously simplified or becomes impossible:

Cué was obsessed with time. I mean, he was looking for
time in space and our continuous, unending journeys
were nothing else but searching. One eternal journey
around Malecón. Like now and at any time of night
and day, we were traversing a landscape full of holes
between Maceo Park and La Punta, with old buildings
which had turned into what people had taken away
from the sea to build Malecón: one more reef subjected
to the impact of salt and moisture on days with waves
and wind, and the sea jumps onto the street and hits
the houses, comes for the coast which had been taken
from it, creates it, makes itself a second coast. Then,
there were parks [...], followed by harbour taverns, [...]
and St Francis' Church by the monastery, opposite the
Exchange and the Customs Office, traces of various
epochs and domination left on this square, [...] we went
down into the tunnel under the bay and paid a short
visit at Matanzas for supper, [...] philosophizing all the
time, aestheticizing, moralizing, [...] - and we always
had time for talking about time (Cabrera Infante, 2016,
pp. $332-333$ ).

In literary tourism, time should be treated in two ways. Firstly, we deal with the time of the literary story, the time of the author and the events described. Secondly, there is the time of the reader/tourist's experience. Travellers follow the time of the literary story, but at the same time construct their own from the experience of literature during the journey. In accepted definitions of literary tourism, this distinction between the time when literature was being created and the time of experiencing it during a journey, is usually ignored. Everything becomes unified, devoid of the different tones of describing and reading. There are no subtle shades of describing the start of literary journeys. Referring to the story on life in a unique Swiss resort, pictured on the pages of "The Magic Mountain", this submersion in time can be treated as constructing a specific personal landscape of tourist experience at literary places.

Life sometimes generates such situations, such landscapes (if we may call so what we have in mind at the moment) where such mixing and blending temporalspatial distances, leading to the absolute homogeneity of everything, is a natural, justified fact; then you can't deprecate somebody who in their free time delves deeply. We mean a stroll along the sea shore, [...] You're going and going... you will never be back at home on time, as you have lost time and time has lost you (Mann, 1982, pp. 244-245). 
Moving in their own time, tourists simultaneously look for the time of the literary story. As a result, they construct and experience their own subjective time. The reader/tourist's wandering and changing of places gives sense to space because tourist time creates tourism space. It is worth going back to Ingarden's thought, mentioned earlier, that "it is by analysing the text and revealing underdefined places, or by clearly realizing what the text says about the presented reality and the ways of evidently capturing it, that the boundaries of concretization are set [...]" (Ingarden, 1964, p. 101; Kobiela, 2011). These two 'temporal orders' may meet then in the literary spaces that have been found.

Following the trail of Thomas Mann's inspiration we may assume that the 'literary landscape' is an effect of experiencing literature by the reader/tourist during the journey. The paths of discovering a work of literature in space are an individual, personal experience of it. Unfortunately, established literary tourist trails are sometimes wounds inflicted on the cities or regions which they traverse. The scars show the violence which affects the tourists' thinking and behaviour. Tourist guidebooks limit the way that surrounding reality should be perceived. They become dressings placed on the wounds that are the result of the visited places losing their originality. Tourists are not authentic there (Kaczmarek, 2018) because they think as guidebooks tell them and follow the set routes. Naturally, going along a tourist trail set by someone who imposes a way of thinking establishes the perception of the world Such dressings are laid on injured places, on wounds inflicted on space by "vandals in sandals" (Lowry, 2018, p. 231), who only deepen these wounds in tourist areas become sick. Rivers of tourists, from the past and today, have made these furrows deeper. New tourist trails, new information boards for visitors reopen wounds that are healing. Injuries to tourism spaces are a consequence of depriving those places of their qualities. They become the same for every traveller who walks along established trails and uses the language of guidebooks, looking for the experience they describe. Planning and fully uncovering what should remain an individual experience and personal discovery, makes areas alike because the way to perceive them is imposed.

Intimacy, mystery and sensitivity have become commodities; they cease to be a personal experience of literary space. Thus, the aleatoric approach to tourist experience can be a remedy for the wounds inflicted on visited spaces. An authentic traveller thinks for him/ herself, and discovers literature independently. Then, the experience is constructed personally and not planned or imposed. In the end, the author and the reader/ tourist create the literary space together.

\section{REFERENCES}

Arystoteles (2003). Fizyka. In: Arystoteles, Dzieła wszystkie (pp. 23-204). Vol. 2. Translated by K. Leśniak. Warszawa: Wydawnictwo Naukowe PWN.

Botterill, D., Platenkamp, V. (2012). Key concepts in tourism research. Londyn: SAGE.

Buczkowska, K. (2008). Turystyka kulturowa. Przewodnik Metodyczny. Poznań: AWF im. Eugeniusza Piaseckiego w Poznaniu.

Cabrera Infante, G. (2009). Moja wina, bo tańczyłem cza-czę. Translated by U. Kropiwiec. Warszawa: Muza.

Cabrera Infante, G. (2016). Trzy pstre tygrysy. Translated by U. Kropiwiec, T. Pindel. Kraków: Universitas.

Cortázar, J. (2013). Gra w klasy. Translated by Z. Chądzyńska. Warszawa: Muza.

Czermińska, M. (2000). Autobiograficzny trójkąt. Świadectwo, wyznanie, wyzwanie. Kraków: Universitas

Eco, U. (1994). Lector in fabula, wspótdziałanie w interpretacji tekstów narracyjnych. Warszawa: PIW.

Gutiérrez, P.J. (2019). Brudna trylogia o Hawanie. Translated by P. Fornelski. Poznań: Zysk i S-ka.

Gwizdalanka, D. (1998). Przewodnik po muzyce kameralnej. Kraków: Polskie Wydawnictwo Muzyczne.

Heidegger, M. (1996). Przyczynki do filozofii (Z wydarzania). Translated by B. Baran, J. Mizera. Kraków: Wydawnictwo Baran i Suszyński.

Ingarden, R. (1964). W sprawie budowy dzieła literackiego: profesorowi Markiewiczowi w odpowiedzi. Pamiętnik Literacki, 55 (1), 183-202.

Kaczmarek, J. (2005). Podejście geobiograficzne w geografii społecznej. Łódź: Wydawnictwo Uniwersytetu Łódzkiego.

Kaczmarek, J. (2016). Spacer po terytoriach niedomkniętych, czyli śladami ekspresji geograficznych. Biatostockie Studia Literaturoznawcze, 9, 237-255.

Kaczmarek, J. (2018). Autentyczność epistemologiczna jako nakaz moralny wyjaśniania rzeczywistości turystycznych. Folia Turistica, 49, 199-220.

Kaczmarek, S., Kaczmarek, J. (2015). Wielość rzeczywistości w przestrzeni turystycznej. Rozwój Regionalny i Polityka Regionalna, 31, 17-32.

Kobiela, F. (2011). Filozofia czasu Romana Ingardena wobec sporów o zmienność świata. Kraków: Universitas.

Konończuk, E. (2014). Między rzeczywistością a reprezentacją. Metafora mapy w powieściach Michela Houellebecqa Mapa i terytorium oraz Guillaume'a Jana Le Cartographe. In: E. Konończuk, E. Nofikow, E. Sidoruk (eds), Geografia i metafora (pp. 175-195). Białystok: Wydawnictwo Uniwersytetu w Białymstoku.

Korpysz, A. (2019). Literackie obrazy Barcelony a doświadczenia turystów. Turystyka Kulturowa, 2, 34-46.

Kowalczyk, A., Kulczyk, S. (2010). Turystyka literacka. In: A. Kowalczyk (ed.), Turystyka zrównoważona (pp. 231-248).Warszawa: Wydawnictwo Naukowe PWN.

Lowry, M. (2018). Pod wulkanem. Translated by K. Tarnowska. Poznań: Rebis.

Mann, T. (1982). Czarodziejska góra. Vol. 2. Translated by J. Kramsztyk. Warszawa: Czytelnik.

Mikołajewski, J. (2011). Rzymska komedia. Warszawa: Agora.

Mikos von Rohrscheidt, A. (2008). Turystyka kulturowa. Fenomen, potencjat, perspektywy. Gniezno: GWSHM Milenium w Gnieźnie. Milne, A.A. (1928). The House at Pooh Corner. London: Methuen. Pessoa, F. (2016). Poezje zebrane Álvaro de Campos. Translated by W. Charchalis. Kraków: Lokator. 
Płocka, S. (2013). Eksploracja przestrzeni turystycznej Paryża na przykładzie szlaków plenerów filmowych. Praca magisterska. Promotor J. Kaczmarek. Łódź: Instytut Geografii Miast i Turyzmu, WNG UŁ.

Roszak, J.M. (2016). Okiem przewodnika krajoznawcy. O potencjale turystyki literackiej w Hrubieszowie. Turystyka Kulturowa, 6, 6-18.

Roszak, J., Godlewski, G. (2013). Homo legens jako homo turisticus. Ku metodologii turystyki literackiej. Folia Turistica, 28, 53-66.

Schulz, B. (b.r.). Republika marzeń. Pobrane z: www.wolnelektury.pl (25.08.2019).

Stasiak, A. (2009). Turystyka literacka i filmowa. In: K. Buczkowska, A. Mikos von Rohrscheidt (eds), Wspótczesne formy turystyki kulturowej (pp. 223-265). Poznań: AWF im. Eugeniusza Piaseckiego w Poznaniu.
Stein, E. (1995). Byt skończony a byt wieczny. Translated by I. Adamska OCD. Poznań: W drodze.

Wasserstein, R.L., Schirm, A.L., Lazar, N.L. (2019). Moving to a World Beyond "p0,005”. The American Statistician, 73 (1), 1-19.

Wawrzyniak, M. (2010). Czytanie miasta - idea produktu turystyki literackiej na przykładzie Łodzi. Turystyka Kulturowa, 3, 16-29.

White, K. (2011). Zarys geopoetyki. Translated by A. Czarnacka. Białostockie Studia Literaturoznawcze, 2, 7-25.

Wittgenstein, L. (2012). Tractatus logico-philosophicus. Translated by B. Wolniewicz. Warszawa: Wydawnictwo Naukowe PWN

Zajas, P. (2008). O „autentyczności” i ponowoczesnym rozumieniu doświadczenia turystycznego. Teksty Drugie, 4, 215-230.

Zmyślony, P. (2000). Literatura jako podstawa tworzenia produktu turystycznego. Problemy Turystyki, XXIV (1-2), 21-31.

Article received: 10 September 2019

Accepted:

22 April 2020 